\title{
CONCEPT OF INTERPRACTICE LEARNING
}

Karelina Olena, Ph. D., Associate Professor, Associate Professor of Department of Economic Cybernetics, Ternopil Ivan Pul'uj National Technical University, 56 Ruska Str., 46001 Ternopil, Ukraine, Karelina@tstu.edu.ua

The new concept «interpractice learning» in the article is proposed. The ground of it are the interactive learning technologies and the methods implementation of activity approach to learning.

Scope of the concept and components of pedagogic technology «interpractice learning» was identify: the goal of learning process, content, forms and learning methods, their sequence, time and stages of application. The learning process goal in interpractice learning is acquirement of activity, which is the object of study. Adequate means to master activity provides interactive learning. That is why their forms and methods in the interpractice learning technology is uses.

Pedagogical conditions of interpractice learning implementation was identify:

- it have restrictions on mastering the activity, which operate with physical objects and living organisms, fully implemented for training professionals who work with information;

- $\quad$ methods of interactive and activity learning are uses;

- requires full immersion in activity so the interpractice can be studied only major discipline for the formation of professional competence;

- most appropriate to implement in the system of professional education which a top aims is mastering multifaceted profession activity.

Example of interpractice learning implementation was present for studying business management process approach. Research carried out for specialty 051 «Economy» and specialties of knowledge domain «07. Management and administration».

Prospects for further research are development of learning cases for interpractice studying economic disciplines. Another aspect of our research will be practical test of learning cases effectiveness.

Keywords: activity approach to learning; formation of professional competence; future professionals of business and management; interactive learning; interpractice learning; pedagogical technology.

Стаття надійшла до редакції 26.09.2016 Прийнято до друку 27.10.2016

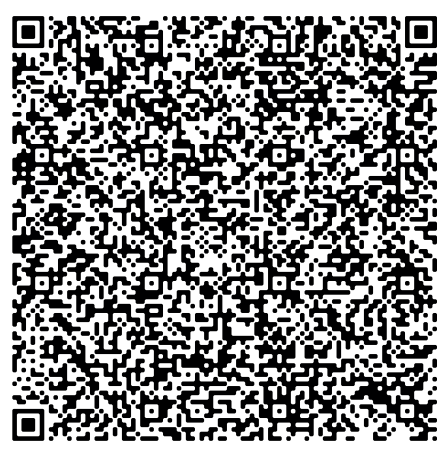

викладач кафедри педагогіки та андрагогіки, Житомирський обласний інститут післядипломної педагогічної освіти, вул. Михайлівська, 15, 10014 м. Житомир, Україна, familyarskaya_la@ukr.net

\section{МОБІЛЬНІСТЬ СУЧАСНОГО ВЧИТЕЛЯ: ТЕОРЕТИКО-МЕТОДОЛОГІЧНИЙ АСПЕКТ}

У статті розглянуто основні теоретико-методологічні аспекти змісту поняття «мобільність» $y$ філософських, педагогічних, психологічних, сочіологічних наукових прачях; акцентовано увагу на характеристиках категорії мобільності, як основної складової професійного розвитку та діяльності сучасного спеціаліста; представлено авторське визначення поняття «мобільність»; обтрунтовано та запропоновано поняття «мобільність педагога» як визначальної вимоги до особистості сучасного педагога; систематизовано характеристичні ознаки мобільності педагога.

Ключові слова: адаптування; мобільність; освіта; особистість; педагог; середовище.

Вступ. Інтерес науковців до проблеми мобільності як однієї з характеристик процесів соціального функціонування людини в сучасному світі, соціальних груп, спільнот, особистісного роз- витку та людства в цілому, в останні роки, стрімко зріс. Свідченням є роботи філософів, соціологів, економістів, психологів, педагогів, представників інших наук і пояснюється це збільшенням 
тенденцій інтенсивності процесів мобільності та посиленням їх значимості в житті суспільства. Будьякий аспект чи тенденція сучасного суспільного розвитку, технологій, а також освіти, так чи інакше виводить науковців на проблему мобільності сучасного педагога у процесі його професіоналізації (Огнев'юк В. О., Сисоєва С. О., 2014, с. 23; Стрюк М. I., 2015).

Мета статті - проаналізувати основні теоретико-методологічні підходи до змісту поняття «мобільність», визначити поняття «мобільність педагога» та систематизувати характеристичні його ознаки.

Теоретичний аналіз поняття мобільності. Аналіз наукових джерел виявив, що підходи до розуміння поняття мобільності склалися у філософській, педагогічній, психологічній, соціологічній науковій думці та представлено з різних сторін.

В основному питання мобільності науковцями розглянуто: в розрізі соціальної готовності до змін (Вебер М., 1990; Сорокін П. О. 1992); як групування якостей особистості (Асмолов О. Г., 1982); як механізм, що зумовлює рівень адаптованості та конкурентоспроможності особистості (Амірова Л. О. 2012; Ігошев Б. М., 2014); як зміну позицій, зумовлену зовнішніми обставинами з однієї сторони, а 3 другої - як внутрішнє самовдосконалення особистості, засноване на цінностях та потребі в саморозвитку (Білик О. М., 2009) тощо.

Розглянемо детальніше основні з них.

Методологічну основу філософського трактування поняття мобільності розглянуто в роботах Голдторпа Д., Вебера М. та Вегенера Б.. В них закладено функціональний підхід до аналізу мобільності як соціального явища (Goldthorpe J. Н., 1987; Weber M., 1990; Wegener B., 1991). Сутність поняття «мобільність» у філософських дослідженнях розкривається через основні закони діалектики і визначається як «зміна взагалі». Тобто, кожному предмету, явищу, процесу властиві постійні кількісні та якісні зміни, які взаємопов'язані. Сутність цих змін проявляється в тому, що поступові кількісні зміни нагромаджуються і призводять до зміни якісного стану. Діє загальний закон буття - закон взаємного переходу кількісних та якісних змін.

Продовжуючи дослідження загальнотеоретичних положень поняття «мобільність», науковці розширили бачення їі розвитку в контексті мобільності особистості, яку зумовлено впливом соціальних і політичних чинників. Зокрема, доповнено умовами, що забезпечують мобільність особистості, визначено їі як прояв активності особистості та основу iï ціннісних орієнтацій, які складають відповідні показники диспозиційної системи регуляції поведінки (Каган М. С., 1997).

В соціологічній науці поняття мобільності Сорокін П. тлумачить у розрізі особистісного розвитку, що передбачає перехід індивіда або соціального об’єкта (цінності) з однієї соціальної позиції в іншу. Охарактеризовані науковцем соціальні процеси переміщення, динаміку, що характеризує мобільність, в подальшому стали називати соціальною мобільністю (Сорокін П. О., 1992).

Сучасні дослідження соціологів базуються на основі результатів досліджень Сорокіна П., розглядаючи проблему мобільності в аспекті соціальної нерівності, де вона означає процес стратифікаційних переміщень індивідів у соціумі між різними рівнями соціальної ієрархії, яка визначається, зазвичай, з точки зору широких професійних чи соціальних класових категорій (Анурін В. Ф., 1993; Щокін Г. В., 2004).

Дослідження мобільності з позиції особистісної якості індивіда має своє відображення і в наукових працях психологів, які відзначають, що в процесі розвитку суспільних відносин людина, як «активний елемент», повинна проявляти мобільність. Інакше може відбутися втрата власного «Я» (Асмолов О. Г., 1982; Брушлинський О. В., 1990).

Стосовно професійної діяльності поняття «мобільність» конкретизується як здатність і готовність особистості досить швидко і успішно оволодівати новою технікою і технологією, набувати відсутні знання і вміння, що забезпечують ефективність адаптації до нової професійної діяльності. Адаптація є невід’ємною властивістю мобільної особистості, що виходить на перший план в умовах нестабільності політичних, соціальноекономічних, суспільних відносин (Дудіна О. М., 1997; Коваліско Н. В., 1999).

Узагальнюючи вище зазначене, відмітимо, що погляди вчених свідчать про те, що домінантою у змісті трактування мобільності особистості є ідея адаптації, гнучкості та швидкості реагування у мінливих, непередбачених умовах фахової діяльності. Мобільність, як один 3 невід'ємних показників професійної і соціальної зрілості суб'єкта, є тією особливою властивістю, яка характеризує внутрішню готовність людини до якісних змін.

Якщо 3 точки зору соціальних наук, що досліджують процеси мобільності, вивчають характер протікання цих процесів, умови та чинники, що на них впливають, то на рівні психологічної парадигми мобільність, насамперед, вивчають через сутнісні характеристики самого індивіда, його особистісні якості та параметри статусної позиції, наприклад, професійної.

3 педагогічної точки зору дослідники вивчають дане поняття 3 різних позицій: як проблему педагогічної освіти спеціалістів різних профілів, як інтегровану якість особистості, як оволодіння конкретними уміннями швидкої перебудови власних дій у відповідності до змін, що відбуваються в суспільстві (Сушенцева Л. Л., 2011; Амірова Л. О., 2012; Биков В. Ю., 2013; Стрюк М. І., Семеріков С. О., Стрюк А. М., 2015). 
Розглядаючи мобільність особистості в освіті дорослих, Сушенцева Л. і Амірова Л. характеризують іï внутрішній зміст як механізм, що дозволяє адаптуватися в швидкоплинних умовах соціального середовища. Протиріччя, що визначені в роботах науковців, обумовлені, з одного боку, значимістю мобільності як властивості та якості фахівця у вирішенні проблем самоідентифікаціі, самореалізації та самоактуалізації кожної особистості, успішної побудови відносин в соціумі, а з іншого - недостатньою розробленістю педагогічних аспектів розвитку мобільності в сучасному освітньому процесі.

Таким чином, вивчення позицій авторів щодо поняття «мобільність» базуються на: по-перше, виявленні сутнісних характеристик феномену мобільності, як внутрішньої якості, риси; по-друге, на підходах до її неперервного формування та розвитку, як зовнішнього руху, переміщення.

В аспекті співвідношення у соціальнопедагогічних і технічних системах видів мобільності (реальної, віртуальної) та з позиції системного підходу, науковці Стрюк М., Семеріков С., Стрюк А. розробили модель мобільності в інформаційному суспільстві, що має три виміри: один - реальний і два - віртуальні. Реальний вимір є спільним для соціально-педагогічних і технічних систем у зв'язку з тим, що передбачає вивчення руху у просторі людей і речей. Вченими визначено, що перший віртуальний вимір відповідає за соціальну мобільність людей, а другий віртуальний вимір за інформаційну мобільність ідей.

Таким чином, мобільність пов'язана з посиленням динамічності соціальних процесів на сучасному етапі розвитку суспільства та освіти, що неминуче призводить до підвищення мобільності людей за найрізноманітнішими векторами їх соціального функціонування (Білик О. М., 2009).

Визначення поняття «мобільність педагога». Перелік визначень зарубіжними та вітчизняними науковцями поняття мобільності багатоаспектний, особливо в літературі з соціології та педагогіки. Але однозначності в розкритті сторін мобільності ми не знаходимо. Інтегруючи точки зору науковців, розуміємо мобільність як особистісну здатність адаптування до швидких змін, модифікації професійної діяльності в умовах нових ситуацій або оперативного знаходження способу застосування знань в знайомих чи нестандартних ситуаціях із найменшим опором та мінімальними втратами щодо власних фізичних, психологічних та емоційних ресурсів. Швидка адаптація в інформаційному світі є однією із складових характеристик мобільності як поняття. Вона не є біологічно зумовленою, тому можливий вплив на їі розвиток впродовж життя.

Мобільність як особистісна здатність адаптування до динамічно мінливих умов сучасного середовища зумовлює можливості не тільки ефективно адаптуватися до них, а й реалізувати себе як суб’єкта активної перебудови життєвих умов та саморозвитку.

Враховуючи вище зазначене, розуміємо мобільність педагога як особистісну здатність адаптування до змін, що забезпечує стабільність розвитку фахівця та активну професійну позицію. Вона є умовою його переміщення 3 позиції на позицію, яке відбувається цілеспрямовано та свідомо. Чим внутрішньо мобільніший педагог, тим краще він орієнтується в ситуації, тим швидше реалізується в соціальній та професійній ієрархії, тим різноманітнішою може бути його педагогічна діяльність.

Узагальнивши результати аналізу наукових підходів виділяємо базові їх позиції, а саме, що мобільність педагога:

- $\quad$ визначається соціальними та особистісними чинниками;

- $\quad$ виступає як результат цілеспрямованого саморозвитку;

- $є$ механізмом особистісної гнучкості та адаптації до змін в умовах професійного середовища;

- $€$ умовою неперервності розвитку особистості.

На основі зіставлення низки думок авторів характерними ознаками мобільності педагога визначаємо:

- $\quad$ властивості і якості особистості (відкритість, гнучкість, оперативність, адаптивність, комунікативність, рефлексивність);

- уміння (самоконтролю, саморегуляції, самооцінювання, цілепокладання, проектування, управління);

- $\quad$ здібності (конструктивність у спільній взаємодії, мисленні, проектуванні необхідних змін розвитку педагогічної ситуації, в мікросоціумі).

Проблема розвитку мобільності фахівця, який має бути конкурентоспроможний на сучасному ринку праці, стосується у першу чергу педагога, так як він розглядається в якості специфічного джерела, наставника, керівника, фасилітатора з питань формування та розвитку мобільної особистості сучасного учня.

Висновки. На основі аналізу філософської, педагогічної, психологічної та інших джерел виявлено, що поняття «мобільність» вивчається у взаємозв’язку декількох наук. Кожна з них розглядає той чи інший їі аспект. Зокрема, частина дослідників розуміють мобільність як процес, частина - як особистісну якість, а деякі визначають її як інтегровану властивість, що забезпечує формування та розвиток необхідних якостей фахівця.

Базуючись на різноаспектних підходах, визначено авторське розуміння поняття мобільності, що включає: здатність особистості до змін, яка не є біологічно зумовленою і забезпечує можливість самореалізації фахівця та поняття «мобільність педагога», як адаптивну здатність, що сприяє профе- 
сійному розвитку та активності фахівця в практичній діяльності при вирішенні навчальних завдань.

Під адаптивною здатністю розуміємо інтегральне утворення взаємозалежних підструктур, де рефлексивні механізми створюють особливий когнітивний досвід, що забезпечує ефективність професійної діяльності педагога. Вважаємо, що здатність відмовитися від стереотипів, готовність до діяльності, взаємодії, перетворення, до творчого осмислення дійсності, критичність мислення, мотивація до самоосвіти є визначальними вимогами до особистості сучасного педагога.

Таким чином, мобільність як педагогічна категорія виражає ідею поступальних змін відповідно освітніх потреб та умов освітнього середовища.
Однак, проблема розвитку мобільності педагога потребує грунтовного дослідження, що зумовлюється низкою чинників до яких належать: зміни, що відбулися у змісті професійної діяльності та зумовлені процесами глобалізації, інтеграції; швидке оновлення інформаційно-комунікаційних технологій та функціональних можливостей сучасних комп'ютерних засобів; потреба суспільства у фахівцях, здатних бути конкурентоспроможними на ринку праці.

Перспективою подальших досліджень є визначення поняття «інформаційно-комунікаційної мобільності педагога» та його сутнісних характеристик.

\section{Література}

1. Амирова Л. А. Развитие личностной мобильности в пространстве непрерывного профессионального образования / Л. А. Адмиралова // Образование через всю жизнь: непрерывное образование в интересах устойчивого развития. - 2012. - №2. - С. 55-57.

2. Анурин В. Ф. Проблема эмпирического измерения социальной стратификации и социальной мобильности / В. Ф. Анурин // Социологические исследования - 1993. - № 4. - С. 87-96.

3. Асмолов А. Г. Основные понятия психологического анализа в теории деятельности / А. Г. Асмолов // Вопросы психологии. - 1982. - №2. - С. 28-32.

4. Биков В. Ю. Мобільний простір і мобільно орієнтоване середовище інтернет-користувача: особливості модельного подання та освітнього застосування / В. Ю. Биков // Інформаційні технології в освіті. 2013. - № 17. - С. 9-37.

5. Білик О. М. Основні напрями збереження і розвитку національного людського капіталу за рахунок активізації трудової мобільності / О. М. Білик // Україна: аспекти праці. - 2009. - № 1. - С.43-46.

6. Брушлинский А. В. Деятельность субъекта и психическая деятельность (деятельность: теория, методология, проблемы) / А. В. Брушлинский. - М.: Политиздат, 1990. - 19 с.

7. Вебер М. Избранные произведения. - М., 1990. - 543 с.

8. Дудина О. М. Профессиональная мобильность: кто и как принимает решение сменить профессию / О. М. Дудина // Социологическое исследование. - 1997. - №11. - С. 22 - 28

9. Игошев Б. М. Сущностно-логический анализ мобильности как межнаучного понятия / Б. М. Игошев // Педагогическое образование в России, 2014. - №1. - С. 105-111

10. Каган М. С. Философская теория ценности / М. С. Каган. - СПб.: Петрополис, 1997. - 416 с.

11. Кльоц Л. А. Використання активних методів у розвитку професійної я-концепції психолога [Електронний ресурс] / Любов Антонівна Кльоц // Технології розвитку інтелекту, № 5, том. 1. - 2014. - Режим доступу: http://goo.gl/89f8CW

12. Коваліско Н. В. Трудова мобільність в умовах регіонального ринку праці : автореф. дис. на здобуття наук. ступеня канд. соціол. наук / Н. В. Коваліско. - Львів, 1999. - 20 с.

13. Косигіна О. В. Педагогічна взаємодія суб’єктів системи післядипломної освіти: зміст і специфіка / О. В. Косигіна // Освіта дорослих: теорія, досвід, перспективи. - 2013, №7 - С. 215-224.

14. Огневюк В. А. К проблеме развития научного направления интегрированного исследования сферы образования / В. А. Огневюк, С. А. Сысоева // Вестник высшей школы. - № 3 (март, 2014). - С. 22-30.

15. Сорокин П. А. Социальна мобильность // Человек. Цивилизация. Общество / П. А. Сорокин. - М.: Политиздат, 1992. - С. 302 - 373. - (Серия «Мыслители ХХ века»).

16. Стрюк М. І. Мобільність: системний підхід / М. І. Стрюк, С. О. Семеріков, А. М. Стрюк // Інформаційні технології і засоби навчання. - 2015. - Т. 49, вип. 5. - С. 37-70. - Режим доступу: http://nbuv.gov.ua/UJRN/ITZN_2015_49_5_7

17. Сушенцева Л. Л. Формування професійної мобільності майбутніх кваліфікованих робітників у професійно-технічних навчальних закладах: теорія і практика: монографія / Лілія Леонідівна Сушенцева; за ред. Н. Г. Ничкало; Інститут професійно-технічної освіти НАПН України. - Кривий Ріг: Видавничий дім, 2011. - 439 с.

18. Щёкин Г. В. Славянство: его место и роль в европейской истории. - К., 2004.

19. Фамілярська Л. Л. Мобільність як перспективна складова освітнього процесу [Електронний ресурс] / Лариса Леонідівна Фамілярська. // Інформаційні технології і засоби навчання, № 41, вип. 3. 2014. - Режим доступу: http://goo.gl/hIfp2a 
20. Wegener B. Job mobility and social ties: social resources, prior job, and status attainment // American social review. 1991. - Vol. 56, № 1. Febr. - P. 6071.

21. Goldthorpe J. H. Social mobility and class structuring modern Britain. - Oxford: Clarendonpress, 1987. $-377 \mathrm{p}$.

22. Kasworm Carol (2011). The Influence of the Knowledge Society: Trends in Adult Higher Education [Електронний ресурс] / The Journal of Continuing Higher Education, 59:104-107, DOI: 10.1080/07377363.2011.568830. - Режим доступу: http://www.carl-abrc.ca/uploads/h_ed_articles/Kasworm.pdf

\title{
МОБИЛЬНОСТЬ СОВРЕМЕННОГО УЧИТЕЛЯ: ТЕОРЕТИКО-МЕТОДОЛОГИЧЕСКИЙ АСПЕКТ
}

\author{
Фамилярська Лариса, преподаватель кафедры педагогики и андрагогики, \\ Житомирский областной институт последипломного педагогического образования, \\ ул. Михайловская, 15, 10014 г. Житомир, Украина, familyarskaya_la@ukr.net
}

В статье рассмотрены основные теоретико-методологические аспекты содержания понятия «мобильность» в философских, педагогических, психологических, сочиологических научных трудах; акцентировано внимание на характеристиках категории мобильности, как основной составляющей профессионального развития и деятельности современного специалиста; представлено авторское определение понятия «мобильность»; обосновано и предложено понятие «мобильность педагога» как определяющей требования к личности современного педагога; систематизированы характеристические признаки мобильности педагога.

Ключевые слова: адаптация; мобильность; образование личность; педагог; среда.

\section{MOBILITY OF MODERN TEACHER: THEORETICAL AND METHODOLOGICAL ASPECTS}

Familyarskaya Larissa, teacher of the Department of Pedagogy and Andragogy, Zhytomyr Regional Institute of Postgraduate Education, Mikhailovskaya Street 15, 10014 Zhitomir, Ukraine, familyarskaya_la@ukr.net

In proposed article considered basic theoretical and methodological approaches of philosophers, sociologists, economists, psychologists, teachers, representatives of other sciences to solve problems of mobility as one of the characteristics in the processes of human social functioning in the modern world, social groups, communities, personal development and humanity in general. The dominant interpretation of individual mobility is the idea of adaptation, flexibility and responsiveness to changing, unpredictable conditions in professional activities.

Mobility as one of the essential parameters of professional and social maturity of person, is the special property that characterizes the human inner willingness to qualitative changes. Integrating scientific points of view, we understand mobility as personal ability to adapt to rapid changes, modifications of professional activity in terms of new conditions or effectively knowledge in familiar or unusual situations with least resistance and minimal losses on their physical, psychological and emotional resources. Rapid adaptation in the information world is one of the constituent characteristics of a mobility concept.

Mobility of teachers should understand as personal ability to adapt to changes, that's ensuring professional stability and active professional position. It is a condition to consciously move from position to position.

Thus, mobility as a pedagogical category expresses the idea of translational changes in accordance with the educational needs and conditions of the educational environment.

However, the problem of teacher mobility requires thorough research, due to several factors including changes in professional activity and due to globalization and integration, rapid updating of information and communication technologies and functionality of modern computer equipment, society need specialists able to be competitive in the labor market.

The prospect of further research is definition of «information and communication teacher mobility» and its essential characteristics.

Key words: adaptation; education; environment; mobility; personality; teacher.

Стаття надійшла до редакції 06.09.2016 Прийнято до друку 27.10.2016 